\title{
PENERAPAN METODE PEM BELAJARAN SIMULASI UNTUK MENINGKATKAN AKTIVITAS DAN PRESTASI BELAJAR EKONOMIKA MIKRO
}

\author{
Daru Wahyuni \\ Kiromim Baroroh
}

Universitas Negeri Yogyakarta

\begin{abstract}
Abstrak
Penelitian ini bertujuan untuk meningkatkan: keaktifan dan prestasi belajar mahasiswa dengan penerapan metode simulasi dalam mata kuliah Ekonomika mikro. Penelitian ini merupakan penelitian tindakan kelas. Setting penelitian adalah mahasiswa reguler semester II, berjumlah 50 orang mahasiswa yang mengambil mata kuliah ekonomika mikro. Rancangan penelitian melibatkan dosen sebagai peneliti utama dan sekaligus sebagai pelaku tindakan, dosen pengamat dan mahasiswa sebagai subyek didik. Cara penelitian dilakukan melalui : 1 . perencanaan, 2 . implementasi tindakan kelas, 3. pemantauan dan evaluasi, 4. analisis dan refleksi, 5. penyimpulan hasil. Pengumpulan data menggunakan observasi, dokumentasi, wawancara dan angket : Uji keabsahan data menggunakan triangulasi metode dan sumber. Penelitian tindakan ini dengan menerapkan metode simulasi dalam pembelajaran ekonomika mikro. Hasil dari penelitian tindakan ini adalah 1) Penerapan metode pembelajaran simulasi dapat meningkatkan aktifitas mahasiswa. Terjadi peningkatan aktivitas belajar dari siklus I ke siklus II, dan dari siklus II ke siklus III. 2) Penerapan metode pembelajaran simulasi dapat mengoptimalkan prestasi belajar siswa. Prestasi belajar siswa mengalami peningkatan dari prestasi belajar siklus I ke siklus II, dan dari siklus II ke siklus III.
\end{abstract}

Kata Kunci: Simulasi, prestasi, ekonomi mikro

\section{A. Pendahuluan}

Ekonomi mikro merupakan mata kuliah wajib tempuh bagi mahasiswa pendidikan ekonomi. Mata kuliah ini memberi gambaran kepada mahasiswa bagaimana perilaku konsumen dan produsen individual serta penentuan harga dan kuantitas faktor pasar, barang, jasa dan factor produksi.

Ekonomi mikro menganalisis bagaimana keputusan produsen dan konsumen mempengaruhi penawaran dan permintaan atas barang dan jasa yang pada akhirnya akan menentukan harga salah satu barang, pada gilirannya akan 
menentukan penawaran dan permintaan barang dan jasa lainnya. Demikian akan terjadi terus menerus. Keseimbangan pasar berbagai macam barang ini kemudian akan membentuk keseimbangan dalam skala makro. Dengan demikian ekonomi mikro merupakan ilmu yang sangat penting dan dapat diterapkan dalam kehidupan sehari-hari.

Proses pembelajaran dapat dikatakan berhasil jika semua aspek pembelajaran dapat saling mendukung dalam menciptakan situasi yang kondusif untuk kegiatan pembelajaran. Proses pembelajaran yang baik tentunya akan berpengaruh pada pemahaman mahasiswa terhadap materi yang disampaikan dosen. Sasaran utama dari kegiatan pembelajaran terletak pada proses belajar peserta didik, yang harus mengutamakan belajar mahasiswa secara aktif, karena sasaran pendidikan adalah proses pembelajaran mahasiswa, bukan semata-mata mengukur hasil belajar mahasiswa. Namun dalam proses pembelajaran masih saja ditemukan kendala-kendala dalam kegiatan pembelajaran.

Penggunaaan metode klasikal atau ceramah dianggap oleh dosen sebagai metode paling mudah untuk mengelola kelas dan bisa mengejar target materi yang harus diselesaikan. Dengan metode ceramah peranan dosen sangat dominan, dosen sebagai subjek penyampai informasi, dosen merupakan pusat perhatian, dosen lebih banyak berbicara sementara mahasiswa mendengarkan atau mencatat hal-hal yang penting. Komunikasi yang terjadi cenderung satu arah di mana alat komunikasi yang utama digunakan adalah berbicara. Karena komunikasi yang terjadi hanya satu arah, maka proses belajar mengajar menjadi kurang menarik bahkan membosankan. Meskipun demikian masih banyak yang tetap menggunakan metode ceramah tanpa variasi lain.

Berdasarkan hasil survai pada saat pra observasi yang dilakukan peneliti pada mata pelajaran ekonomika mikro diketahui bahwa salah satu kendala yang dirasakan oleh dosen dalam pembelajaran ekonomika mikro adalah kurangnya kerjasama antar mahasiswa saat pembelajaran berlangsung dan pada saat diskusi kelas, sementra kemampuan mahaiswa tidak sama. Dengan adanya kerja sama diharapkan siswa yang cakap akan membantu siswa yang kurang cakap, demikian pula mahasiswa yang kurang cakap berani bertanya pada mahasiswa yang cakap dalam pembelajaran ekonomi mikro.

Data untuk melihat tingkat prestasi belajar mahasiswa dapat dilihat dari hasil Ujian Akhir Semester II. Hasil ujian semester mahasiswa masih dalam kategori rendah, yaitu sebagian besar mahasiswa berada di bawah patokan nilai kognitif ekonomika mikro yakni 65.

Berdasarkan pengamatan dan interview dari beberapa mahasiswa, diperoleh kenyataan bahwa : 1.Pada umumnya tingkat partisipasi mahasiswa 
dalam proses pembelajaran rendah, 2. Mahasiswa pasif dan kurang bersemangat dalam proses pembelajaran, 3. Mahasiswa kurang mampu berkomunikasi secara lisan, sehingga jarang menyampaikan gagasan, 4. Mahasiswa jarang mengajukan petanyaan.

Berdasarkan permasalahan tersebut, maka melalui penelitian tindakan kelas ini peneliti bermaksud mencari alternatif dan solusi. Metode pembelajaran yang akan digunakan dalam penelitian ini adalah menerapkan metode simulasi. Metode pembelajaran simulasi dapat menggambarkan keadaan sebenarnya dari suatu keadaan, penyederhanaan dari suatu fenomena di dunia nyata. Simulasi adalah suatu tiruan atau perbuatan berpura-pura saja (Sunaryo, 1989:137). Dalam setiap bentuk simulasi akan terjadi hal-hal sebagai berikut: (1) para pemain memegang peranan yang mewakili dunia nyata, dan juga membuat keputusan-keputusan dalam mereaksi penilaian mereka terhadap setting yang meeka temukan sendiri, (2) mereka mengalami perbuatan-perbuatan tiruan yang berhubungan dengan keputusan-keputusan mereka dan penampilan umum mereka, (3) mereka memonitor hasil kegiatan masing-masing, dan diarahkan untuk merefleksi terhadap hubungan antara keputusan-keputusan mereka sendiri dan konsekuensi-konsekuensi akhir yang menunjukkan gabungan dari berbagai perbuatan.

Pembelajaran simulasi mempunyai beberapa tujuan yaitu: 1) tujuan langsung yang terdiri dari: a) untuk melatih keterampilan tertentu, baik yang bersifat profesional maupun bagi kehidupan sehari-hari, b) untuk memperoleh pemahaman tentang suatu konsep atau prinsip, c) untuk latihan memecahkan masalah 2) tujuan tidak langsung a) Untuk meningkatkan aktivitas belajar dengan melibatkan dirinya dalam mempelajari situasi yang hampir serupa dengan kejadian yang sebenarnya. b) Untuk memberikan motivasi belajar karena anak sangat menarik dan menyenangkan anak-anak. c) Melatih anak bekerja sama dalam kelompok dengan lebih efektif. d) Menimbulkan dan memupuk daya kreatif anak.e) Melatih anak untuk memahami dan menghargai peranan anggota lain.

Karena aktivitas belajar itu banyak sekali macamnya maka para ahli mengadakan klasifikasi atas macam-macam aktivitas. Paul D Dierich dalam Oemar Hamalik, (2001), membagi kegiatan dalam 8 kelompok yaitu: 1) kegiatan-kegiatan visual : Membaca, melihat gambar-gambar, mengamati eksperimen, demonstrasi, pameran, dan mengamati orang lain bekerja atau bermain. Ini terkait dengan kemampuan indera penglihatan. 2) kegiatan-kegiatan lisan (oral) terdiri dari: Mengemukakan suatu fakta atau prinsip, menghubungkan suatu kejadian, mengajukan pertanyaan, memberi saran, mengemukakan pendapat, wawancara, diskusi, dan ineterupsi. 4) kegiatan-kegiatan mendengarkan terdiri dari: mendengarkan penyajian bahan, mendengarkan percakapan atau diskusi kelompok, mendengarkan suatu permainan, mendengarkan radio. 5) kegiatankegiatan menulis terdiri menulis cerita, menulis laporan, memeriksa karangan, 
bahan-bahan kopi, membuat rangkuman, mengerjakan tes, dan mengisi angket. 6) kegiatan-kegiatan menggambar terdiri dari: Menggambar, membuat grafik, chart, diagram peta, dan pola. 7) kegiatan-kegiatan metrik terdiri dari melakukan percobaan, memilih alat-alat, melaksanakan pameran, membuat model, menyelenggarakan permainan, menari dan berkebun. 8) kegiatan-kegiatan mental terdiri dari: merenungkan, mengingat, memecahkan masalah, menganalisis, faktor-faktor, melihat, hubungan-hubungan, dan membuat keputusan. 9) kegiatan-kegiatan emocional minat, membedakan, berani, tenang dan lain-lain. Kegiatan-kegiatan dalam kelompok ini terdapat dalam semua jenis kegiatan dan overlap satu sama lain.

Berbagai teori, penelitian dan pelaksanaan pembelajaran membuktikan bahwa dosen sudah harus mengubah metode pembelajaran ceramah secara murni tersebut dengan menyusun dan melaksanakan pembelajaran seperti yang dikemukakan Anita Lie (2007: 5) yaitu :a) Pengetahuan ditemukan, dibentuk dan dikembangkan oleh mahasiswa.b) Mahasiswa membangun pengetahuan secara aktif. c) Pengajar perlu mengembangkan kompetensi dan kemampuan mahasiswa. d) Pendidikan adalah interaksi pribadi di antara para mahasiswa dan interaksi antara dosen dan mahasiswa.

Sumadi Suryabrata (2006) menyatakan bahwa prestasi belajar adalah kemampuan siswa yang berupa, penguasaan pengetahuan, sikap, dan keterampilan, yang dicapai dalam belajar setelah mereka melakukan kegiatan belajar. Prestasi belajar digunakan sebagai suatu gambaran dari suatu penguasaan kemampuan para peserta didik sebagaimana ditetapkan untuk suatu matakuliah tertentu. Setiap usaha yang dilakukan dalam kegiatan pembelajaran baik oleh dosen sebagai pengajar, maupun oleh mahasiswa bertujuan untuk mencapai prestasi yang setinggi tingginya. Prestasi belajar dinyatakan dengan skor hasil tes atau angka.

Metode pembelajaran ini dipilih karena metode pembelajaran ini lebih menekankan pada keaktifan peserta didik dalam membangun konsep/pengetahuan yang dimiliki untuk mengatasi permasalahan yang dihadapi. Dalam pembelajaran ini, pendidik bersikap interaktif dalam pembelajaran dan menjadi fasilitator atau mediator dari lingkungan bagi peserta didik dalam pembelajaran. Penilaian proses pembelajaran merupakan bagian integral dalam pembelajaran, dilakukan melalui observasi terhadap unjuk kerja peserta didik, di samping dalam bentuk tes/ujian (Dandan Supratman: 2001).

Berdasarkan latar belakang masalah, tujuan permasalahan dari penelitian ini adalah Untuk meningkatkan keaktifan dan prestasi belajar mahasiswa dengan penerapan metode simulasi dalam mata kuliah Ekonomika mikro. 


\section{B. Metode Penelitian}

Penelitian ini merupakan penelitian tindakan kelas. Gagasan pokok penelitian ini adalah bahwa orang yang melakukan tindakkan harus juga terlibat dalam proses penelitian sejak awal. Mereka tidak hanya menyadari perlunya melaksanakan program tindakan tertentu, tetapi secara emosional ikut terlibat dalam program tindakan tersebut ( Suwarsih Madya, 1994).

Setting penelitian ini adalah J urusan Pendidikan Ekonomi Fakultas IImu Sosial Dan Ekonomi - Universitas Negeri Yogyakarta. Penelitian tindakan ini dilaksanakan pada semester genap tahun 2009/2010 untuk matakuliah Ekonomi Mikro. Penelitian ini akan melibatkan mahasiswa reguler semester II sebanyak 50 mahasiswa. Pihak- pihak yang dilibatkan dalam penelitian ini adalah : seorang dosen sebagai peneliti utama dan sekaligus sebagai pelaku tindakan berjumlah 1 orang, dosen pengamat (observer) berjumlah 2 orang, mahasiswa sebagai subjek didik yang berjumlah 50 orang.

Teknik pengumpulan data yang akan dipergunakan dalam penelitian ini adalah observasi, wawancara, dokumentasi dan angket. Prosedur penelitian ini merupakan penelitian tindakan yang mengacu model Kemmis dan Mc Taggart (1988). Oleh karena itu, cara penelitian dilakukan melalui beberapa tahapan sebagai berikut: Tahap Perencanaan, Implementasi Tindakan, Tahap pemantauan dan evaluasi, analisis dan refleksi.

Data yang akan diperoleh dari hasil penelitian ini adalah data kualitatif dan data kuantitatif sebagai pendukungnya. Analisis data dilakukan menurut karakteristik masing- masing data yang terkumpul. Dari data yang terkumpul diklasifikasikan dan dikategorikan secara sistematik dan menurut karakteristiknya. Sementara data kuantitatif dianalisis dengan metode diskriptif kuantitatif. Temuan ini akan digunakan untuk melaksanakan tindakan selanjutnya.

Keabsahan data dalam penelitan in dilakukan dengan teknik triangulasi. Moleong (2005: 330) mengatakan triangulasi adalah teknik pemeriksaan keabsahan data yang memanfaatkan sesuatu diluar data itu untuk keperluan pengecekan atau sebagai pembanding data itu. Penelitian ini menggunakan triangulasi sumber dan metode.

Indikator Keberhasilan Tindakan adalah adanya respon yang baik dari mahasiswa, yang ditandai meningkatnya aktifitas mahasiswa, dan prestasi belajar mahasiswa pada matakuliah Ekonomika Mikro. Secara kuantitatif diharapkan 80\% mahasiswa dapat aktif dalam pembelajaran dan minimal $75 \%$ mahasiswa mendapatkan nilai di atas 70 .

\section{Hasil dan Pembahasan}




\section{Pelaksanaan Tindakan Siklus I}

Langkah pertama dalam penelitian ini adalah perencanaan kegiatan. Kegiatan yang dilakukan pada tahap ini adalah :

a. Membuat Rencana Pelaksanaan Pembelajaran (RPP) tentang materi tentang Teori produksi dengan kompetensi dasar menjelaskan konsep Teori Produksi untuk siklus I. RPP digunakan sebagai acuhan dosen dalam melaksanakan pembelajaran.

b. Menyusun Lembar Kerja Kelompok (LKK) untuk siklus I dan siklus II. LKK ini digunakan sebagai media pembelajaran mahasiswa untuk memahami materi dengan menggunakan teknik simulasi.

c. Menyusun soal dan kunci jawaban tes. Tes digunakan untuk mengukur hasil belajar mahasiswa terhadap materi yang dipelajari. Tes yang diberikan berupa kuis individu yang diberikan pada akhir siklus.

d.Menyusun dan menyiapkan lembar observasi pembelajaran dan lembar aktivitas mahasiswa saat belajar kelompok.

e. Menyiapkan panduan pedoman wawancara untuk dosen dan mahasiswa.

f. Menyiapkan peralatan untuk mendokumentasikan kegiatan selama proses pembelajaran berlangsung seperti kamera.

Pada tahap pelaksanaan tindakan ini dosen melaksanakan pembelajaran dengan metode pembelajaran simulasi. Pembelajaran dilakukan berdasarkan RPP yang sebelumnya telah disiapkan oleh peneliti, yaitu dengan materi konsep teori produksi. RPP tersebut terlebih dahulu telah dikonsultasikan kepada ahli ekonomi mikro. Selama tindakan berlangsung, peneliti dibantu oleh seorang observer mengamati secara langsung tanpa mengganggu jalannya proses pembelajaran.

Pertemuan pertama pada siklus I dilaksanakan pada hari Jum'at, 16 April 2010 di aula Tjut Nya Dien. Pelaksanaan tindakan pertemuan I ini meliputi langkahlangkah sebagai berikut:

a) Dosen membuka pelajaran dengan mengucapkan salam, mengecek presensi mahasiswa kemudian melakukan presentasi secara singkat dan menyampaikan kompetensi dasar yang akan dicapai.

b) Dosen menyampaikan garis besar materi, sebelum memulai pelajaran dosen mengadakan apersepsi yaitu memberikan pertanyaan siapa yang mengetahui tentang teori produksi? Setelah itu dosen memberikan sedikit tentang teori produksi secara singkat. 
c) Kemudian dosen memberikan kesempatan kepada mahasiswa untuk menanyakan hal-hal yang dianggap sulit pada dosen.

d) Peneliti dibantu rekan observer membagi mahasiswa ke dalam kelompokkelompok kecil. Pembagian kelompok dengan memperhatikan heterogenitas mahasiswa berdasarkan jenis kelamin dan prestasi akademik. Siswa dibagi dalam kelompok. Satu kelompok berisi 6-7orang. Satu kelas beranggotakan 8 kelompok.

e) Dosen menginstruksikan mahasiswa menempatkan diri sesuai kelompoknya masing-masing. Namun tidak semua kelompok bergegas untuk membentuk kelompok. Ada anggota kelompok yang merasa kurang puas atas anggota kelompoknya, ada juga mahasiswa yang lupa dengan anggota kelompoknya sehingga banyak mahasiswa yang maju ke depan dan bertanya pada peneliti dengan kelompoknya sehingga suasana kelas menjadi gaduh.

f) Kemudian peneliti memberikan gambaran kepada mahasiswa tentang kegiatan yang akan dilaksanakan dalam pembelajaran, serta menjelaskan secara singkat tata cara mahasiswa beaktivitas dalam kelompok. Pembelajaran tentang teori produksi dengan menggunakan pizza.

g) Pada putaran I, Mahasiswa bekerja dalam kelompok masing-masing untuk membuat pizza dalam jangka waktu 3 menit. Kemudian dinilai oleh dosen siapa yang paling banyak membuat pizza dengan kualitas yang sudah ditentukan. Selanjutnya dibuat putaran dua selama tiga menit pula. Ternyata ada peningkatan produksi antara putaran satu dan putaran 2.

h) Pada pembuatan pizza yang menunjukkan the law diminishing product, kelompok yang dapat membuktikan 3 kelompok, namun ada beberapa kelompok yang tidak dapat membuktikan karena mereka tidak serius pada waktu memproduksi barang.

i) Kemudian peneliti memberikan Lembar Kerja Kelompok (LKK) kepada tiap kelompok untuk mendiskusikan materi atau topik. Mahasiswa dengan anggota kelompoknya bekerja sesuai dengan aturan pembelajaran simulasi.

j) Setelah demo dosen meminta kepada mahasiswa menyimpulkan hasil pembelajaran yang telah berlangsung Mengenai kesimpulan dari the law diminishing return, pengertian produksi, dan faktor-faktor yang meningkatkan produksi.

k) Setelah demo selesai, pada tahapan evaluasi dengan menggunakan tes dapat dilihat bahwa mereka yang mengerjakan tugas.

Pertemuan kedua pada Kamis, 22 April 2010, pukul 12.10-13.50, di

Ruang G.108 FISE UNY temuan ini dilakukan evaluasi terhadap simulasi yang telah dilakukan pada pertemuan sebelumnya. 
Hasil pengamatan yang dilakukan untuk hasil belajar mahasiswa diukur pada setiap akhir siklus. Sedangkan untuk aktivitas mahasiswa diukur atau dapat dilihat setiap pertemuan per siklus.

Hasil tindakan terhadap prestasi belajar mahasiswa pada siklus I ini dapat dilihat pada tabel 1 Pada tabel 1 ini memperlihatkan bahwa prestasi belajar mahasiswa mengalami peningkatan yang cukup signifikan setelah menggunakan metode simulasi. Hasil prestasi mahasiswa pada kuis siklus I dapat diketahui melalui tabel di bawah ini.

Tabel 1. Tingkat Prestasi dan Aktivitas Mahasiswa Pada Siklus I

\begin{tabular}{|c|c|c|c|c|}
\hline & \multicolumn{2}{|c|}{ Prestasi } & \multicolumn{2}{c|}{ Aktivitas } \\
\hline Kategori & Frekuensi & $\begin{array}{c}\text { Persentase } \\
(\%)\end{array}$ & Frekuensi & $\begin{array}{c}\text { Persentase } \\
(\%)\end{array}$ \\
\hline Istimewa & 8 & 16 & 1 & 2 \\
\hline Baik & 13 & 26 & 9 & 18 \\
\hline Cukup & 15 & 30 & 32 & 64 \\
\hline Kurang & 14 & 28 & 8 & 16 \\
\hline Jumlah & 50 & 100 & 50 & 100 \\
\hline
\end{tabular}

Sumber : Data primer yang sudah diolah

Aktivitas siswa diketahui dari Peningkatan kerjasama siswa, keaktifan bertanya, keaktivan mengerjakan soal, perhatian siswa ketika di kelas, dan menunjukkan minat untuk belajar ekonomi mikro.

Dapat disimpulkan secara umum bahwa tingkat aktivitas mahasiswa pada siklus I ini terlihat sebagian mahasiswa masih merasa canggung untuk aktif dalam simulasi. Mereka masih terlihat stagnan sebagaimana pola belajar awal yang menggunakan ceramah, sehingga mahasiswa cenderung pasif meskipun dosen dan peneliti telah beraktivitas untuk memberikan semacam perubahan. Sehingga dapat dilihat pada aspek keikutsertaan memberi pendapat masih rendah hal ini terlihat pada ketekunan mahasiswa dalam menghadapi tugas masih rendah, yaitu ketika mahasiswa mendapat tugas untuk mengerjakan Lembar Kerja Kelompok (LKK), banyak mahasiswa yang mengeluh ketika diberi tugas oleh dosen. Sehingga dalam mengerjakan lembar kerja kelompok sebagian mahasiswa tidak mengemukakan gagasan masing-masing terkait dengan permasalahan yang diberikan. 
Pada indikator keaktifan bertanya dan menjawab pertanyaan dosen. Mahasiswa tidak langsung bertanya apabila ada masalah yan mengganjal. Dalam keaktifan menjawab pertanyaan terlihat bahwa setiap jawaban yang muncul, baik dalam kelompok masing-masing atau kelompok besar, belum ditanggapi dengan aktif oleh para mahasiswa lain sehingga harus dipandu oleh dosen dan peneliti.

Pada indikator keaktifan mengerjakan tugas yang diberikan kelompok ini terlihat bahwa tidak banyak mahasiswa yang ingin mendalami lebih jauh materi yang dipelajari, hal ini terlihat dari kurang aktifnya mahasiswa untuk bertanya pada dosen. Mahasiswa juga belum terlihat antusias dalam beraktivitas menyelesaikan tugas yang diberikan oleh dosen.

Perhatian siswa pada materi pembelajaran juga masih kurang. Siswa ada yang mengobrol dengan temannya ketika simulasi berlangsung. Mereka membicarakan hal-hal di luar materi pelajaran.

Keaktifan yang ditunjukkan dengan minat untuk belajar ekonomi mikro diketahui bahwa belum banyak mahasiswa ingin berprestasi sebaik mungkin pada kelompoknya, sehingga masih ada mahasiswa yang tidak bersungguh-sungguh saat mengerjakan soal diskusi dalam kelompoknya hal ini masih terlihat saat pengerjaan lembar kerja kelompok dalam satu kelompoknya masih ada mahasiswa yang mengobrol dengan teman satu kelompoknya.

Hasil wawancara terhadap mahasiswa dapat tercakup dalam hasil wawancara tersebut adalah :

a) Dapat di uraikan bahwa sebagian besar setelah memasuki siklus I Tanggapan mahasiswa terhadap proses pembelajaran dengan metode simulasi. Mereka masih bingung dengan materi yang diberikan namun menurut sebagian besar mahasiswa proses pembelajaran dianggap santai dan tidak membosankan. Tetapi dosen beserta peneliti tidak henti-hentinya memacu mahasiswa untuk aktif dan menuntut keberanian dan kecerdasan dalam mengeluarkan pendapat karena masih banyak mahasiswa yang cenderung gaduh saat pembelajaran berlangsung.

b) Perhatian mahasiswa selama proses pembelajaran dengan menggunakan metode simulasi ini dapat tergambar dengan intensitas keributan yang dilakukan mahasiswa masih terlihat pada beberapa mahasiswa bahkan pada saat diskusi dilakukan masih ada mahasiswa yang asik sendiri tanpa ikut memecahkan permasalahan pada lembar kerja kelompok. Sebagian mahasiswa terlihat lebih banyak 
menghabiskan waktu untuk mencetak nilai sebanyak-banyaknya agar tidak kalah dengan teman atau kelompok lain.

c) Adanya ketekunan belajar dan usaha mendalami materi dengan menggunakan metode simulasi sudah mulai terlihat dalam ketepatan serta kedisiplinan beberapa mahasiswa dalam mengerjakan baik tugas individu atau kelompok. Oleh karena pada umumnya mahasiswa merasa senang, tugas yang diberikan dengan kerumitan dan setiap tugas menuntut mahasiswa, memecahkan masalah dan menyimpulkan pemecahan masalah tersebut dapat benar-benar dikerjakan seoptimal mungkin. Namun masih ada beberapa mahasiswa yang mengerjakan tugas yang diberikan oleh dosen dan peneliti dengan tidak serius.

d) Saran untuk penelitian terhadap proses pembelajaran menggunakan metode simulasi bahwa sebagian besar mahasiswa cenderung untuk menjawab bahwa metode simulasi ini sudah bagus namun hanya membutuhkan waktu yang cukup banyak supaya semua kelompok dapat mempresentasikan hasil simulasinya.

Refleksi pada siklus I dilakukan dengan mengkaji hasil dan permasalahan yang dihadapi. Pada siklus I diperoleh data bahwa mahasiswa antusias dalam pembelajaran tersebut, walaupun belum optimal. Hal ini disebabkan mahasiswa belum terbiasa menggunakan metode pembelajaran simulasi tersebut.

Beberapa kelemahan yang ditemukan dalam siklus I adalah :

1) Pada simulasi ini hanya beberapa anak yang bertugas aktif membuat simulasi produksi pizza, sehingga selain yang mendapat tugas produksi banyak yang tidak beraktifitas.

2) Posisi tempat duduk antar kelompok yang terlalu dekat yang memungkinkan mahasiswa untuk saling menganggu antar kelompok. Selain itu posisi tempat duduk yang menyulitkan mobilitas peneliti untuk menilai aktivitas mahasiswa.

3) Belum ada kesadaran dari dalam diri mahasiswa untuk berani bertanya dan mengemukakan pendapat, peran dosen masih besar untuk memotivasi mahasiswa agar mau bertanya, meskipun cara dosen dalam memotivasi mahasiswa belum maksimal.

4) Tingkat aktivitas mahasiswa saat diskusi kelompok berlangsung dan saat presentasi hasil simulasi masih kurang terutama terlihat pada saat presentasi. 
5) Dosen masih banyak berperan dalam diskusi dan presentasi hasil simulasi yang ditunjukkan dengan pertanyaan-pertanyaan dari mahasiswa yang ditanggapai dosen.

6) Keterbatasan waktu sehingga menyebabkan dosen menyampaikan materi kurang maksimal dan pada tiap pertemuan pada siklui I hanya tiga kelompok yang dapat menyampaikan hasil simulasinya didepan kelas.

Berdasarkan hasil analisis dan refleksi siklus I yaitu dengan melihat dari tingkat aktivitas mahasiswa yang masih rendah pada lembar observasi dan hasil wawancara yang dilakukan pada siklus I, sehingga dilakukan penyempurnaan.

Langkah tindak lanjut untuk meningkatkan aktivitas mahasiswa peneliti melakukan wawancara dengan observer untuk merancang pemecahan kekurangan-kekurangan pada siklus I. Hasil diskusi ini diperoleh pemecahan masalah antara lain :

1) Dibuat simulasi yang dapat mengaktifkan seluruh peserta dalam kelas. Kalaupun hanya beberapa anak yang ikut berpartisipasi untuk beraktivitas, mahasiswa yang lain perlu mendapatkan tugas, agar berkonsentrasi dan memperhatikan pada materi simulai

2) Mengatur posisi kelompok agar tidak terlalu berdekatan serta urut nomor kelompok untuk memilimalisir gangguan antar kelompok dan agar mobilitas peneliti saat observasi menjadi lebih leluasa.

3) Dosen lebih tegas untuk mengatur mahasiswa yang ramai dengan langsung memberikan pertanyaan bagi mahasiswa yang ramai atau tidak memperhatikan penjelasan dari dosen. Bagi mahasiswa yang mencontek akan dikenakan sanksi berupa pengurangan nilai.

4) Memacu mahasiswa agar lebih berani mengajukan pertanyaan dan mengemukakan pendapat, salah satu cara yang digunakan oleh dosen dalam hal ini adalah dengan memberikan contoh-contoh yang dekat dengan lingkungan sekitar agar mahasiswa dapat memahami maksud dosen dan dapat memberikan tanggapan terhadap permasalahan yang dilontarkan dosen

5) Mendorong mahasiswa agar mahasiswa mampu beaktivitas dengan teman satu kelompok saat diskusi berlangsung dan saat presentasi hasil dilakukan.

6) Memberikan pengertian kepada mahasiswa harus belajar secara mandiri tidak selalu bergantung kepada dosen karena keberhasilan dalam belajar juga ditentukan oleh kemandirian mahasiswa bukan dengan bantuan dosen semata.

7) Berusaha menyampaikan materi dengan singkat dan jelas, dan memberikan handout kepada mahasiswa agar mahasiswa dapat belajar sebelum mengikuti pelajaran sehingga pada pertemuan selanjutnya 
tidak hanya tiga kelompok yang dapat mempresentasikan hasil simulasinya ke depan kelas.

\section{Pelaksanaan Tindakan Siklus I I}

Seperti halnya siklus I kegiatan pertama yang dilakukan adalah perencanaan. Kegiatan yang dilakukan pada tahap ini adalah : Membuat RPP tentang materi Teori Cost dengan kompetensi dasar menjelaskan konsep Teori Cost untuk siklus II. RPP digunakan sebagai acuhan dosen dalam melaksanakan pembelajaran.

Pada pelaksanaan tindakan pembelajaran dilakukan berdasarkan RPP yang sebelumnya telah disiapkan oleh peneliti, yaitu dengan materi konsep teori produksi. RPP tersebut terlebih dahulu telah dikonsultasikan kepada ahli ekonomi mikro. Selama tindakan berlangsung, peneliti dibantu oleh seorang observer mengamati secara langsung tanpa mengganggu jalannya proses pembelajaran.

Pertemuan pertama pada siklus II dilaksanakan pada hari J um'at, 30 April 2010 di ruang G01.108. Pelaksanaan tindakan pertemuan II ini meliputi langkah-langkah sebagai berikut:

1. Dosen membuka pelajaran dengan mengucapkan salam, mengabsen mahasiswa kemudian melakukan presentasi secara singkat dan menyampaikan kompetensi dasar yang akan dicapai.

2. Kelas dibagi menjadi dua kelompok besar. Posisi dua kelompok duduk tidak saling berdekatan agar tidak saling mengganggu kelompok lain.

3. masing-masing kelompok besar dibagi menjadi 7 kelompok kecil: kelompok 1 berisi 1 orang, kelompok 2 terdiri 2 orang, kelompok 3 terdiri 3 orang, kelompok 4 terdiri 4 orang, kelompok 5 terdiri 5 orang, kelompok 6 terdiri 6 orang, kelompok 7 terdiri 7 orang.

4. Pada putaran I mahasiswa memproduksi buku, semua tahapan memproduksi dilakukan sendiri oleh masing-masing anggota kelompok secara sendiri-sendiri. Dalam jangka 5 menit. Kemudian mencatat data hasil simulasi di lembar kerja mahasiswa. Kemudian mendiskusikan hasil terkait dengan konsep biaya produksi dan produktivitas tenaga kerja. Dosen menanyakan apa yang bisa dilakukan untuk meningkatkan produktivitas tenaga kerja kepada mahasiswa? Mahasiswa menjawab dengan insentif, melakukan spesialisasi kerja. Dosen memberi waktu 1 menit kepada kelompok untuk mendiskusikan apa yang harus dilakukan kelompok agar produktivitas meningkat untuk persiapan ke2. Kemudian jawaban mahasiswa dibahas bersama dosen.

5. Pada putaran II mahasiswa memproduksi buku, dosen membolehkan mahasiswa untuk membagi pekerjaan. 
6. Pada putaran III mahasiswa memproduksi buku, dosen membolehkan mahasiswa untuk membagi pekerjaan dan menambah modal berupa spidol.

7. Mahasiswa di minta menuliskan di LKS hasil produksi mereka dan berapa biaya yang diperlukan untuk memproduksi

8. Mahasiswa diminta menyimpulkan hasil simulasi

9. Dosen memberi penguatan

Pertemuan kedua pada tanggal Kamis, 6 Mei 2010, Jam: 12.10-13.50, di Ruang G.108 FISE UNY. Pertemuan ini dilakukan evaluasi terhadap simulasi yang telah dilakukan pada pertemuan sebelumnya dengan mengerjakan soal tes.

Aktivitas mahasiswa diketahui terjadi peningkatan kerja sama mahasiswa, keaktifan bertanya, keaktifan mengerjakan soal, perhatian siswa ketika di kelas, dan menunjukkan minat untuk belajar ekonomi mikro. Berikut ini ditunjukkan kategoi hasil tindakan terhadap prestasi belajar dan aktivitas mahasiswa pada siklus II ini dapat dilihat pada tabel 3.

Tabel 3 . Tingkat Prestasi dan Aktivitas Mahasiswa Pada Siklus II

\begin{tabular}{|c|c|c|c|c|}
\hline & \multicolumn{2}{|c|}{ Prestasi } & \multicolumn{2}{c|}{ Aktivitas } \\
\hline Kategori & Frekuensi & $\begin{array}{c}\text { Persentase } \\
(\mathbf{\%})\end{array}$ & Frekuensi & $\begin{array}{c}\text { Persentase } \\
(\%)\end{array}$ \\
\hline Istimewa & 10 & 20 & 9 & 18 \\
\hline Baik & 17 & 34 & 30 & 60 \\
\hline Cukup & 17 & 34 & 7 & 14 \\
\hline Kurang & 6 & 12 & 4 & 8 \\
\hline Jumlah & 50 & 100 & 50 & 100 \\
\hline
\end{tabular}

Sumber : Data primer yang sudah diolah

Dapat disimpulkan secara umum bahwa tingkat aktivitas mahasiswa pada siklus II ini terlihat sebagian mahasiswa sudah kelihatan aktif dalam simulasi. Dengan permainan yang mengaktifkan seluruh mahasiswa, mereka lebih terlihat serius dalam mengerjakan simulasi.

Pada indikator keaktifan bertanya dan menjawab pertanyaan dosen. Mahasiswa sudah langsung bertanya apabila ada masalah yan mengganjal. Mereka juga sudah diskusi dalam kelompok besar dan kecil.

Pada indikator keaktifan mengerjakan tugas yang diberikan kelompok terlihat bahwa cukup banyak mahasiswa yang ingin mendalami lebih jauh materi yang dipelajari, hal ini terlihat dari semakin aktifnya mahasiswa untuk bertanya pada dosen. Mahasiswa juga belum terlihat semakin antusias dalam beaktivitas menyelesaikan tugas yang diberikan oleh dosen. Namun masih ada 
beberapa mahasiswa yang terlihat tidak aktif berdiskusi dalam kelompok.Perhatian siswa pada materi pembelajaran juga sudah cukup. Siswa ada yang mengobrol dengan temannya ketika simulasi berlangsung. Tidak terlihat siswa mengantuk atau bercakap-cakap dengan temannya.

Keaktifan yang ditunjukkan dengan minat untuk belajar ekonomi mikro diketahui bahwa banyak mahasiswa ingin berprestasi sebaik mungkin pada kelompoknya, sehingga mahasiswa bersungguh-sungguh saat mengerjakan soal diskusi dalam kelompoknya.

Pada akhir proses pembelajaran siklus II ini, wawancara dilakukan terhadap beberapa mahasiswa ekonomi mikro. Hasil wawancara menunjukkan bahwa mereka lebih senang menggunakan metode simulasi dalam pembelajaran sehingga minat mereka untuk belajar ekonomi meningkat. Berikut ini hasil wawancara dengan mahasiswa :

1. Dapat di uraikan bahwa sebagian besar setelah memasuki siklus II tanggapan mahasiswa terhadap proses pembelajaran dengan metode simulasi. Mereka sudah cukup jelas dengan materi yang diberikan namun menurut sebagian besar mahasiswa proses pembelajaran dianggap santai dan tidak membosankan.

2. Perhatian mahasiswa selama proses pembelajaran dengan menggunakan metode simulasi ini dapat tergambar dengan intensitas keributan yang dilakukan mahasiswa sudah dapat mengendalikan keributan.

3. Adanya ketekunan belajar dan usaha mendalami materi dengan menggunakan metode simulasi sudah mulai terlihat dalam ketepatan serta kedisiplinan sebagian besar mahasiswa dalam mengerjakan baik tugas individu atau kelompok. Oleh karena pada umumnya mahasiswa merasa senang, tugas yang diberikan dengan kerumitan dan setiap tugas menuntut mahasiswa, memecahkan masalah dan menyimpulkan pemecahan masalah tersebut dapat benar-benar dikerjakan seoptimal mungkin. Namun masih ada beberapa mahasiswa yang mengerjakan tugas yang diberikan oleh dosen dan peneliti dengan tidak serius.

d) Saran untuk penelitian terhadap proses pembelajaran menggunakan metode simulasi bahwa sebagian besar mahasiswa cenderung untuk menjawab bahwa metode simulasi ini sudah bagus namun hanya membutuhkan waktu yang cukup banyak supaya semua kelompok dapat mempresentasikan hasil simulasinya.

Refleksi pada siklus II dilakukan dengan mengkaji hasil dan permasalahan yang dihadapi. Pada siklus II diperoleh data bahwa 
mahasiswa antusias dalam pembelajaran tersebut, walaupun masih perlu perbaikan.

Beberapa kelemahan yang ditemukan dalam siklus II adalah :

1. Belum ada kesadaran dari dalam diri mahasiswa untuk berani bertanya dan mengemukakan pendapat, peran dosen masih besar untuk memotivasi mahasiswa agar mau bertanya, meskipun cara dosen dalam memotivasi mahasiswa belum maksimal.

2. Tingkat aktivitas mahasiswa saat diskusi kelompok berlangsung dan saat presentasi hasil simulasi masih kurang terutama terlihat pada saat presentasi.

3. Dosen masih banyak berperan dalam diskusi dan presentasi hasil simulasi yang ditunjukkan dengan pertanyaan-pertanyaan dari mahasiswa yang ditanggapai dosen.

Berdasarkan hasil analisis dan refleksi siklus II yaitu dengan melihat dari tingkat aktivitas mahasiswa yang masih belum mencapai indikator pada lembar observasi dan hasil wawancara yang dilakukan pada siklus II, sehingga dilakukan penyempurnaan.

Sebagai langkah tindak lanjut untuk meningkatkan aktivitas mahasiswa peneliti melakukan wawancara dengan observer untuk merancang pemecahan kekurangan-kekurangan pada siklus II. Hasil diskusi ini diperoleh pemecahan masalah antara lain :

1.Dosen lebih tegas untuk mengatur mahasiswa yang ramai dengan langsung memberikan pertanyaan bagi mahasiswa yang ramai atau tidak memperhatikan penjelasan dari dosen. Bagi mahasiswa yang mencontek akan dikenakan sanksi berupa pengurangan nilai.

2. Memacu mahasiswa agar lebih berani mengajukan pertanyaan dan mengemukakan pendapat, salah satu cara yang digunakan oleh dosen dalam hal ini adalah dengan memberikan contoh-contoh yang dekat dengan lingkungan sekitar agar mahasiswa dapat memahami maksud dosen dan dapat memberikan tanggapan terhadap permasalahan yang dilontarkan dosen.

4. Memberi reward bagi mahasiswa yang dapat menjawab dengan tepat baik pertanyaan dosen maupun temannya

5. Memberikan pengertian kepada mahasiswa harus belajar secara mandiri tidak selalu bergantung kepada dosen karena keberhasilan dalam belajar juga ditentukan oleh kemandirian mahasiswa bukan dengan bantuan dosen semata.

\section{Pelaksanaan Tindakan Siklus I I I}


Siklus 3 dilakukan pada kamis, 20 Mei 2010. Membahas tentang Struktur Pasar (Ciri-ciri empat struktur pasar).

Kegiatan perencanaan tindakan yang dilakukan pada tahap ini adalah :

a. Membuat Rencana Pelaksanaan Pembelajaran (RPP) tentang materi tentang Struktur Pasar (Ciri-ciri empat struktur pasar). RPP digunakan sebagai acuhan dosen dalam melaksanakan pembelajaran.

b. Menyusun Lembar Kerja Kelompok (LKK) untuk siklus III. LKK ini digunakan sebagai media pembelajaran mahasiswa untuk memahami materi dengan menggunakan teknik simulasi. Simulasi ini dirancang agar lebih mengaktifkan mahasiswa.

c. Menyusun soal dan kunci jawaban tes. Tes digunakan untuk mengukur hasil belajar mahasiswa terhadap materi yang dipelajari. Tes yang diberikan berupa kuis individu yang diberikan pada akhir siklus.

d. Menyusun dan menyiapkan lembar observasi pembelajaran dan lembar aktivitas mahasiswa saat belajar kelompok.

g. Menyiapkan panduan pedoman wawancara untuk dosen dan mahasiswa.

h. Menyiapkan peralatan untuk mendokumentasikan kegiatan selama proses pembelajaran berlangsung seperti kamera.

Pada pelaksanaan tindakan pada pertemuan pertama pada siklus III dilaksanakan pada hari Kamis, 20 Mei 2010 di ruang G01.108. Pelaksanaan tindakan pertemuan III ini meliputi langkah-langkah sebagai berikut:

1. Dosen membuka pelajaran dengan mengucapkan salam, mencek kehadiran mahasiswa kemudian melakukan presentasi secara singkat dan menyampaikan kompetensi dasar yang akan dicapai.

2. Kelas dibagi empat kelompok beranggotakan 1 orang, 2orang, 3 orang, dan banyak orang. Masing-masing kelompok diberi 1 buah permen.

3. Masing-masing permen tersebut akan dibeli oleh dosen. Mereka diminta untuk menjual berdasarkan harga dasar Rp.100,00-Rp.1000,00.

4. Siswa menawarkan harga permen pada harga yang mereka anggap rasional.

5. Masing-masing siswa menawarkan harga permennya

6. Dosen mengajak mahasiswa untuk menyimpulkan bentuk pasar penjual permen.

7. Siswa dibagi dalam kelompok kecil 2- 3 orang.

8. Masing-masing kelompok menebak siapa diantara kelima orang yang maju ke depan yang berlaku sebagai monopolis. 
9. Pada pertanyaan ke-2, ada pertanyaan siswa yang sudah mengarah pada siapa monopolisnya, maka dosen memberikan pertanyaan tambahan siapa masing-masing bentuk pasar dari kelima tersangka yang ada di depan.

10. Mahasiswa diminta menyimpulkan hasil simulasi

11. Dosen memberi penguatan, dilanjutkan doa penutup dan salam

Pertemuan kedua pada tanggal Kamis, 6 Mei 2010, Jam: 12.10-13.50, di Ruang G.108 FISE UNY. Pertemuan ini dilakukan evaluasi terhadap simulasi yang telah dilakukan pada pertemuan sebelumnya dengan mengerjakan soal tes.

\section{Hasil Tindakan}

Hasil pengamatan yang dilakukan untuk prestasi belajar mahasiswa diukur pada setiap akhir siklus. Sedangkan untuk aktivitas mahasiswa diukur atau dapat dilihat setiap pertemuan per siklus. Di bawah ini hasil pengamatan yang dilakukan oleh peneliti dan dosen selama proses pembelajaran berlangsung pada siklus III mengenai prestasi belajar mahasiswa dan aktivitas mahasiswa adalah sebagai berikut: di bawah ini.

Dari hasil prestasi mahasiswa pada kuis siklus III dapat diketahui melalui tabel

Tabel 5 . Tingkat Prestasi dan Akivitas Mahasiswa Pada Siklus II I

\begin{tabular}{|c|c|c|c|c|}
\hline Kategori & Frekuensi & $\begin{array}{c}\text { Persentase } \\
(\mathbf{\%})\end{array}$ & Frekuensi & $\begin{array}{c}\text { Persentase } \\
(\mathbf{\%})\end{array}$ \\
\hline Istimewa & 15 & 30 & 14 & 26 \\
\hline Baik & 23 & 46 & 33 & 66 \\
\hline Cukup & 12 & 24 & 3 & 6 \\
\hline Kurang & 0 & 0 & 0 & 0 \\
\hline Jumlah & 50 & 100 & 50 & 100 \\
\hline
\end{tabular}

Sumber : Data primer yang sudah diolah

Aktivitas siswa diketahui dari Peningkatan kerjasama siswa, keaktifan bertanya, keaktivan mengerjakan soal, perhatian siswa ketika di kelas, dan menunjukkan minat untuk belajar ekonomi mikro.

Dapat dilihat pada siklus III ini berdasarkan aspek atau indikator yang diamati, terlihat bahwa tingkat aktivitas mahasiswa sebagian besar berada pada kategori tinggi yaitu sebanyak 33 siswa (66\%). Sementara itu, 14 (26\%) mahasiswa berada kategori sangat tinggi. Sehingga 92\% mahasiswa berada pada ketori tinggi dan sangat tinggi .

Dapat disimpulkan secara umum bahwa tingkat aktivitas mahasiswa pada siklus III ini terlihat sebagian mahasiswa mahasiswa sudah aktif dalam simulasi. Dengan permainan yang mengaktifkan seluruh mahasiswa, mereka lebih terlihat serius simulasi. 
Pada indikator keaktifan bertanya dan menjawab pertanyaan dosen. Mahasiswa sudah langsung bertanya apabila ada masalah yan mengganjal. Mereka juga sudah diskusi dalam kelompok besar dan kecil. Dosen sangat menghargai pendapat mahasiswa dan diberi reward berupa pujian bagi mahasiswa.

Pada indikator keaktifan mengerjakan tugas yang diberikan kelompok terlihat bahwa cukup banyak mahasiswa yang ingin mendalami lebih jauh materi yang dipelajari, hal ini terlihat dari semakin aktifnya mahasiswa untuk bertanya pada dosen. Mahasiswa juga belum terlihat semakin antusias dalam beaktivitas menyelesaikan tugas yang diberikan oleh dosen. Namun masih ada beberapa mahasiswa yang terlihat tidak aktif berdiskusi dalam kelompok.

Perhatian siswa pada materi pembelajaran juga sudah cukup. Siswa tidak ada yang mengobrol dengan temannya ketika simulasi berlangsung. Tidak terlihat siswa mengantuk atau bercakap-cakap dengan temannya

Keaktifan yang ditunjukkan dengan minat untuk belajar ekonomi mikro diketahui bahwa banyak mahasiswa ingin berprestasi sebaik mungkin pada kelompoknya, sehingga mahasiswa bersungguh-sungguh saat mengerjakan soal diskusi dalam kelompoknya.

Hasil wawancara menunjukkan bahwa mereka lebih senang menggunakan metode simulasi dalam pembelajaran sehingga minat mereka untuk belajar ekonomi meningkat. Hasil wawancara terhadap mahasiswa dapat tercakup dalam hasil wawancara tersebut adalah :

a) Dapat di uraikan bahwa sebagian besar setelah memasuki siklus III tanggapan mahasiswa terhadap proses pembelajaran dengan metode simulasi. Mereka sudah cukup jelas dengan materi yang diberikan namun menurut sebagian besar mahasiswa proses pembelajaran dianggap santai dan tidak membosankan.

b) Perhatian mahasiswa selama proses pembelajaran dengan menggunakan metode simulasi ini dapat tergambar dengan intensitas keributan yang dilakukan mahasiswa sudah dapat mengendalikan keributan.

c) Adanya ketekunan belajar dan usaha mendalami materi dengan menggunakan metode simulasi sudah mulai terlihat dalam ketepatan serta kedisiplinan sebagian besar mahasiswa dalam mengerjakan baik tugas individu atau kelompok. Oleh karena pada umumnya mahasiswa merasa senang, tugas yang diberikan dengan kerumitan dan setiap tugas menuntut mahasiswa, memecahkan masalah dan menyimpulkan pemecahan masalah tersebut dapat benar-benar dikerjakan seoptimal mungkin. Namun masih ada beberapa mahasiswa yang mengerjakan tugas yang diberikan oleh dosen dan peneliti dengan tidak serius.

d) Saran untuk penelitian terhadap proses pembelajaran menggunakan metode simulasi bahwa sebagian besar mahasiswa cenderung untuk menjawab bahwa 
metode simulasi ini sudah bagus namun hanya membutuhkan waktu yang cukup banyak supaya semua kelompok dapat mempresentasikan hasil simulasinya.

Refleksi pada siklus III dilakukan dengan mengkaji hasil dan permasalahan yang dihadapi. Pada siklus III diperoleh data bahwa mahasiswa antusias dalam pembelajaran tersebut, sehingga hasil penelitian ini sudah dianggap cukup karena telah memenuhi criteria yang ditentukan yaitu adanya respon yang baik dari mahasiswa, yang ditandai meningkatnya aktifitas mahasiswa minimal $80 \%$ mahasiswa aktif dalam proses pembelajaran, dan prestasi belajar mahasiswa pada matakuliah Ekonomika Mikro minimal 75\% mahasiswa dapat menguasai $70 \%$ materi.

Diketahui bahwa pada siklus III ini berdasarkan aspek atau indikator yang diamati, terlihat bahwa tingkat aktivitas mahasiswa sebagian besar berada pada kategori tinggi yaitu sebanyak 33 siswa (66\%). Sementara itu, 14 (26\%) mahasiswa berada kategori sangat tinggi. Sehingga $92 \%$ mahasiswa berada pada ketori tinggi dan sangat tinggi .

Pada prestasi mahasiswa pada kuis siklus III dapat dilihat bahwa sebanyak 15 mahasiswa ( 30\%) yang memperoleh nilai dalam kategori istimewa, sebanyak 23 mahasiswa ( 46\%) memperoleh kategori baik, sebanyak 12 mahasiswa (24\%) yang memperoleh nilai dengan kategori cukup dan sebanyak 0 mahasiswa $(0 \%)$ yang memperoleh kategori kurang.

Prestasi mahasiswa pada kuis siklus I di atas dapat dilihat bahwa sebanyak 8 mahasiswa (16\%) yang memperoleh nilai dalam kategori istimewa, sebanyak 13 mahasiswa (26\%) memperoleh kategori baik, sebanyak 15 mahasiswa ( $30 \%$ ) yang memperoleh nilai dengan kategori cukup dan sebanyak 14 mahasiswa ( 28) yang memperoleh kategori kurang. Pada kuis siklus II di atas dapat dilihat bahwa sebanyak 10 mahasiswa (20\%) yang memperoleh nilai dalam kategori istimewa, sebanyak 17 mahasiswa (34\%) memperoleh kategori baik, sebanyak 17 mahasiswa (34\%) yang memperoleh nilai dengan kategori cukup dan sebanyak 6 mahasiswa (6\%) yang memperoleh kategori kurang. Pada kuis siklus III di atas dapat dilihat bahwa sebanyak 15 mahasiswa ( 30\%) yang memperoleh nilai dalam kategori istimewa, sebanyak 23 mahasiswa ( 46\%) memperoleh kategori baik, sebanyak 12 mahasiswa (24\%) yang memperoleh nilai dengan kategori cukup dan sebanyak 0 mahasiswa (0\%) yang memperoleh kategori kurang. Dengan demikian terjadi peningkatan prestasi mahasiswa dari setiap siklus.

Pada Aktivitas Mahasiswa diketahui pada siklus I ini berdasarkan aspek atau indikator yang diamati, terlihat bahwa tingkat aktivitas mahasiswa sebagian besar masih pada kategori sedang yaitu sebanyak 32 mahasiswa (64\%), 8 mahasiswa (16\%) dalam kategori rendah, 9 mahasiswa(18\%) berada dalam kategori tinggi, dan hanya 1 (2\%) mahasiswa dalam kategori sangat tinggi. Pada siklus II ini berdasarkan aspek atau indikator yang diamati, terlihat bahwa tingkat 
aktivitas mahasiswa sebagian besar masih pada kategori tinggi yaitu sebanyak 30 siswa (60\%). Namun secara keseluruhan masih $78 \%$ siswa yang aktif, sehingga belum memenuhi indikator yang diharapkan, yakni $80 \%$.

Dari siklus ke siklus diketahui terjadi peningkatan aktivitas dan prestasi belajar mahasiswa. Pada siklus III diperoleh data bahwa mahasiswa antusias dalam pembelajaran tersebut, sehingga hasil penelitian ini sudah dianggap cukup karena telah memenuhi kriteria yang ditentukan yaitu adanya respon yang baik dari mahasiswa, yang ditandai meningkatnya aktifitas mahasiswa minimal $80 \%$ mahasiswa aktif dalam proses pembelajaran, dan prestasi belajar mahasiswa pada matakuliah Ekonomika Mikro minimal 75\% mahasiswa dapat menguasai $70 \%$ materi yang ditandai dengan nilai di atas 70 .

\section{Simpulan dan Saran}

Berdasarkan pembahasan yang telah dilakukan pada bab sebelumnya secara umum dapat disimpulkan bahwa penerapan metode pembelajaran simulasi dapat meningkatkan prestasi belajar dan aktivitas pembelajaran. Adapun kesimpulan secara rinci adalah :

1. Penerapan metode pembelajaran simulasi dapat meningkatkan aktifitas mahasiswa. Hal ini ditunjukkan dengan peningkatan persentase keaktifan yang diperoleh dari lembar observasi dan angket. Terjadi peningkatan aktivitas belajar dari siklus I ke siklus II, dan dari siklus II ke siklus III.

2. Penerapan metode pembelajaran simulasi dapat mengoptimalkan prestasi belajar siswa. Prestasi belajar siswa mengalami peningkatan dari prestasi belajar siklus I ke siklus II, dan dari siklus II ke siklus III.

Adapun saran yang dapat diberikan berdasarkan hasil penelitian dan pembahasan adalah sebagai berikut: 1) Dosen diharapkan dapat mempelajari pedoman pelaksanaan simulasi dalam kelas. Melalui pelaksanaan pembelajaran simulasi dengan baik mahasiswa akan lebih berhasil dalam menguasai materi pelajaran sehingga siswa termotivasi dalam mengikuti kegiatan pembelajaran dan aktif dalam tugas yang diberikan oleh gurunya. 2)Dosen dapat menggunakan metode simulasi ini karena memiliki keistimewaan yaitu menggabungkan antara ceramah, diskusi, dan demonstrasi yang dapat meningkatkan aktivitas ketika pembelajaran yang berlangsung. Keterbatasan penelitian ini adalah: Perlu waktu yang cukup banyak untuk menggunakan model simulasi. Apabila metode ini digunakan terus menerus mahasiswa akan mengalami kebosanan sehingga perlu variasi dalam menggunakan metode pembelajaran di kelas. 


\section{Daftar Pustaka}

Lie ,Anita. 2007. Mempraktekkan Cooperative Learning di Ruang - Ruang Kelas. Jakarta: Grasindo

Supratman, Dandan. (2001). Konstruktivisme dalam Pembelajaran, Makalah

Sunaryo (1989). Strategi Belajar M engajar Ilmu Pengetahuan Sosial.Malang: Penerbit IKIP malang

Hamalik,Oemar, 2001. Proses Belajar M engajar. Jakarta: Bumi Aksara

Suryabrata,Sumadi. 2006. Psikologi Pendidikan. Jakarta : PT Raja Grafindo Persada

Madya,Suwarsih, 1994. Suwarsih Madya. (1994). Panduan Penelitian Tindakan.

Yogyakarta : Lembaga Penelitian IKIP Yogyakarta

Kemmis S dan Mc Taggart . (1988 ) . The Action Research Planner. Deakin: Deakin University Press.

Moleong, Lexy.J.. 2005. Metodologi Penelitian Kualitatif. Bandung : PT Remaja Rosdakarya

Sardiman AM. (2003). Interaksi \& Motivasi Belajar Mengajar, Jakarta: Rajawali Press 